\title{
Women Empowerment through Processing and Marketing of Minor Millets Value Added Products: A way for Doubling the Farmers Income
}

\author{
G. S. Chikkanna*, K. Thulasiram, B. G. Prakash, D. S. Ambika, \\ K. R. Shashidar and K. S. Anilkumaur \\ College of Horticulture, ICAR-Krishi Vigyan Kendra, Kolar-563 103, India \\ *Corresponding author
}

\section{A B S T R A C T}

\begin{tabular}{|l|}
\hline Ke y w o r d s \\
$\begin{array}{l}\text { Empowerment, } \\
\text { Rural Women, } \\
\text { Value Addition, } \\
\text { Minor Millets etc }\end{array}$ \\
\hline Article Info \\
\hline $\begin{array}{l}\text { Accepted: } \\
\text { 15 December } 2019 \\
\text { Available Online: } \\
\text { 20 January } 2020\end{array}$ \\
\hline
\end{tabular}

To uplift the livelihood and financial conditions of the rural women value addition of minor millets can offer tremendous opportunity not only to income rather it increase national productivity and generates employment but also helps to develop economic independence and personal and social upliftment. Smt. Rathnamma is one such example who is from a small village named Gundamanatta in Srinivaspur Taluk of Kolar district. We have formed "Vaibhav Siridhanya Swasahaya Sanga" for processing of Minor Millets. We conducted a five days vocational on campus training programme on "Women Empowerment through Value addition, Marketing and Health benefits of Minor Millets" at ICAR-KVK, Kolar on from 3 to 7.7.2017. In training programme, learned processing of minor millets in to different value added products like Diabetic mix, Upam mix, Dosa mix, Idly mix, Minor Millets rice and Pappads and their packaging. Accordingly, we have conducted awareness programme on production technology and their value addition at Gundamanatta on 24.7.2017 and same day distributed seeds for cultivation through Department of Agriculture, Srinivasapura and progressive famers. Looking at her enthusiasm and zeal, we have approached Dept. of Agriculture, Srinivasapura and facilitated procurement of minor millets processing machine at subsidized rate for the group. We have established "Minor Millet Processing Unit" at Gundamanatta. Linked for online marketing of value added products through "Farm Setu" online portal and helped to get FSSAI and GST number for marketing. Facilitated to start Savi Ruchi canteen at DC office, Kolar weekly once serves Minor Millets food in the canteen. She was awarded "Taulk Level Best Farmers Award" by UAS Bangalore. The entrepreneur expressed income generated was Rs. 480000/- per year. This helps employment creation and income to the farm women.

\section{Introduction}

Millets are nutri cereals comprising of Sorghum, Pearl millet, Finger millet (major millets) Foxtail, little, Kodo, Proso and Barnyard millet (minor millets). These are one of the oldest foods known to humanity (Gopalan $\mathrm{C}$ et. Al.). These are one of the several species of coarse cereal grasses in the family Poaceae, cultivated for their small edible seeds. They are highly nutritious, nonglutinous and not acid forming foods. Hence they are soothing and easy to digest.

They contain high amounts of dietary fibre, Bcomplex vitamins, essential amino and fatty acids and vitamin E. They are particularly high in minerals, iron, magnesium, 
phosphorous, potassium and release lesser percentage of glucose over a longer period of time causing satiety which lowers the risk of diabetes. These grains are high in carbohydrates, with protein content varying from6 to11 percent and fat varying from1.5 to5 percent.

Millets are typically annuals and range in height from 30 to $130 \mathrm{~cm}$ with the exception of sorghum and pearl millet, which has stalks 1.5 to $3 \mathrm{~m}$ tall and about $2.5 \mathrm{~cm}$ thick. The inflorescences may be spikes orracemes, in which the flowers are borne on stalks of about equal length along an elongated axis, orpanic les with dense clusters of small florets. With the exception of pearl millet, seeds remain closed in hulls after threshing. Hulled seeds are usually creamy white (D Vijayalakshmi et. $A l$.).

In India, millets has been a staple diet and a main source of income for farmers especially in the semi-arid regions. They are important food and fodder crop in the semi-arid tropics (SAT) of the world and grows in both kharif and rabi seasons. These grains represent the major source of dietary energy and protein for more than a billion people in the semi-arid tropics.

Entrepreneurs are not only born but can also be trained and developed. Mrs. Rathnamma is one such example who is from a small village named Gundamanatta in Srinivaspur Taluk of Kolar district. She completed PUC and got married to Sri Narayaswamy who is a farmer and is blessed with two children. The family has 3 acres of land growing Mango, Ragi and rearing sericulture.

Mrs. Rathnamma was interested in Value addition of Agricultural and Horticultural produce. She is a leader for 10 SHG groups. She was interested to do own business in her home at free time. She was earlier preparing Mango pickle and supplying to different shops in Srinivaspura Taluk. She was interested to go for minor millets processing and value added products preparation. She approached KVK and explained about her needs and looking into her interest we conducted a group discussion and formed interested farm women as a SHG group of twenty women exclusively for preparation of value added products of minor millets. We have formed "Vaibhav Siridhanya Swasahaya Sanga" for preparation value added products and marketing of minor millets.

The main objectives of this study includes, to reduce post-harvest losses in Minor Millets through skill development among women for processing and value addition. And to generate rural employment by linking women to market. Also to make the women of SHG economically independent.

\section{Materials and Methods}

\section{Technology}

Considering the importance to conduct vocational training programme on "Minor Millets value addition, Branding and marketing" improves the women's economic security, increases employment and nutritional security. (UAS,Dharwad

\section{Interventions}

Initially we have conducted FLD on Nutritional garden at Primary school, Gundamanatta, Srinivasapura TQ. She met KVK Scientist (Home Science) to discuss opportunities of processing of agricultural crops. Scientist (Home Science) did group discussion with women farmers and selection of Leader and Group Member: Smt. Rathnamma, 45 Years, 3 acres of land growing Mango, Ragi and rearing Sericulture. Based on enthusiaism and interest on processing Smt. Rathnamma, was selected as leader for that group. 
The present study was conducted a five days vocational on campus training programme on "Women Empowerment through Value addition, Marketing and Health benefits of Minor Millets" at ICAR-KVK, Kolar on from 3 to 7.7.2017 for this group. The technical sessions included specialized lectures on 'Health benefits, value addition and opportunities in marketing value added products of minor millets' by Dr. G.S. Chikkanna, Scientist (Home Science).

The post lunch sessions were dedicated to the hands on training on processing of minor millets in to different value added products like Diabetic mix, Upam mix, Dosa mix, Idly mix, Minor Millets rice and Papads and their packaging. The participants were given hands on training of preparation of various above mentioned products. At first different recipes were prepared in small quantities by involving the farm women and making them to understand thoroughly about the importance of standardization of ingredients, maintenance of quality of the produce and also hygiene to be maintained during preparation of products. The prepared products were packed by using LDPE and HDPE pouches.

After that we have discussed with SHG group leader Mrs. Ratnamma about raw material for processing of Minor Millets. We came to know that she was purchasing raw material from market through middle men for processing and value addition. Then we have decided to motivate the group to grow minor millets in farmer's field at Gundamanatta and surrounding villages.

Accordingly we have conducted a training programme on production technology of miner millets and their value addition at Gundamanatta on 24.7.2017. On the same day we have distributed Same, Navane and Araka seeds in collaboration with Department of Agriculture, Srinivaspura and other two progressive farmers who have supplied Same and Araka. More than 25 farmers have grown Minor Millets by more than 60 acres of farmer's field. With these she was able to procure raw material within her village at a cheaper rate

\section{Results and Discussion}

Marketing Support to beneficiaries with established agencies to market their produce

The products prepared from minor millets by selected beneficiaries were marketed by direct selling, through established Self Help Groups, Krishi melas, Dasara Festival, Udyana Mela, Mago and Jackfruit Mela, Lalbagh Bengaluru, Flower Show organized by Dept.Horticulture, Kolar, KVK programmes.

Linked for online marketing of value added products through "Farm Setu" online portal and helped to get FSSAI and GST number for marketing. Facilitated to start Savi Ruchi canteen at DC office, Kolar weekly once serves Minor Millets food in the canteen. More than 65 farmers have started for growing Minor millets in around villages and also started consuming minor millets diet.

Facilitated to start Savi Ruchi canteen at DC office, Kolar weekly Twice serves Minor Millets food in the canteen (Dept. Of women and child development) The group members also got the tender for running office canteen in the District Collector Office at Tamaka, Kolar District Collectorate in 2018.

Iron enriched Minor Millets Health drink Mix was developed to combat anemia. Already nutritional analysis has completed. So in future with the approval of District Collector and Dept of Women and child Development this mix to be introduced in ten schools as pilot basis to overcome anemia. 
The table. 4 shows that she spent total of Rs. $94,250 /-$ on purchase of raw material in the year 2017-18 and Rs. 6,35,780/- in the year
2018-19. After established Minor Millets Processing unit she can able to process large quantity of minor millets.

Fig.1 Economic of Minor Millets Value added products

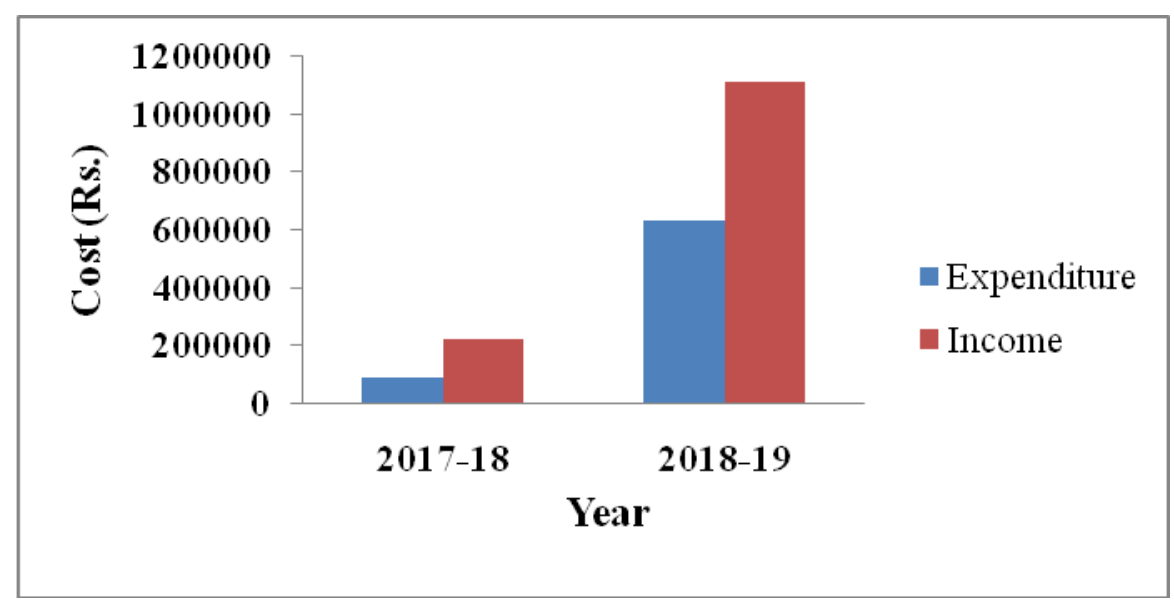

Table.1 Training methods preferred by SHG women

\begin{tabular}{|l|c|}
\hline Training method & Percentage of preference \\
\hline Demonstration & 98 \\
\hline $\begin{array}{l}\text { Lecture with } \\
\text { projected aids }\end{array}$ & 91 \\
\hline Video film & 90 \\
\hline Exhibition & 80 \\
\hline Field visit & 75 \\
\hline
\end{tabular}

Table.2 Socio - demographic profile of women members of SHG group

\begin{tabular}{|l|l|}
\hline \multicolumn{1}{|c|}{ Variables } & \multicolumn{1}{c|}{ Category } \\
\hline Age & 26-35/36-40 Years \\
\hline Education & Illiterate/ High School/ TCH \\
\hline Occupation & Housewife/Labourer \\
\hline Type of family & Nuclear/ joint \\
\hline Family size & 2-4 members/ 5-7 members \\
\hline Number of children & One /Two \\
\hline
\end{tabular}


Table.3 Survey on knowledge about minor millets among the Women farmers

\begin{tabular}{|l|c|c|}
\hline Variables & Before training & After training \\
\hline Awareness & Yes & Yes \\
\hline Consumption & No & Yes \\
\hline Cultivation & No & Yes \\
\hline Value addition & No & Yes \\
\hline
\end{tabular}

Table.4 Amount Spent on purchase of raw material

\begin{tabular}{|c|c|c|c|}
\hline Sl.No & Raw material & $\begin{array}{c}\text { 2017-18 } \\
\text { (Cost.Rs) }\end{array}$ & $\begin{array}{c}\text { 2018-19 } \\
\text { (Cost.Rs) }\end{array}$ \\
\hline 1 & Foxtail Millet & $15500 /-$ & $165000 /-$ \\
\hline 2 & Proso millet & $13200 /-$ & $146000 /-$ \\
\hline 3 & Little millet & $19800 /-$ & $45000 /-$ \\
\hline 4 & Barnyard millet & $11500 /-$ & $75000 /-$ \\
\hline 5 & Kodo millet & $12700 /-$ & $34000 /-$ \\
\hline 6 & Masala Products & $13750 /-$ & $145000 /-$ \\
\hline 7 & $\begin{array}{l}\text { Packaging } \\
\text { Material }\end{array}$ & $7800 /-$ & $25780 /-$ \\
\hline & Total & $94,250 /-$ & $6,35,780 /-$ \\
\hline
\end{tabular}

Table.5 Net Profit from Minor Millets value added products

\begin{tabular}{|c|c|c|c|}
\hline Sl.No & Raw material & $\begin{array}{l}\text { 2017-18 } \\
\text { (Cost.Rs) }\end{array}$ & $\begin{array}{l}\text { 2018-19 } \\
\text { (Cost.Rs) }\end{array}$ \\
\hline 1 & Minor Millets Dosa Mix & $32450 /-$ & $195000 /-$ \\
\hline 2 & Minor Millets Idly Mix & $43200 /-$ & $167000 /-$ \\
\hline 3 & Minor Millets Heath Malt & $23200 /-$ & $175000 /-$ \\
\hline 4 & Minor Millets Payasam Mix & $12000 /-$ & $85000 /-$ \\
\hline 5 & Minor Millets Upam Mix & $22700 /-$ & $76000 /-$ \\
\hline 6 & Minor Millets Pappad & $33750 /-$ & 77000/- \\
\hline 7 & Minor Millets Rice & $56800 /-$ & 340780/- \\
\hline \multirow{2}{*}{\multicolumn{2}{|c|}{ Total }} & $224100 /-$ & $1115780 /-$ \\
\hline & & $\begin{array}{l}224100- \\
94250\end{array}$ & $1115780-635780$ \\
\hline & Net Profit & $129850 /-$ & $480000 /-$ \\
\hline & B:C ratio & $1: 1.72$ & $1: 2.32$ \\
\hline
\end{tabular}



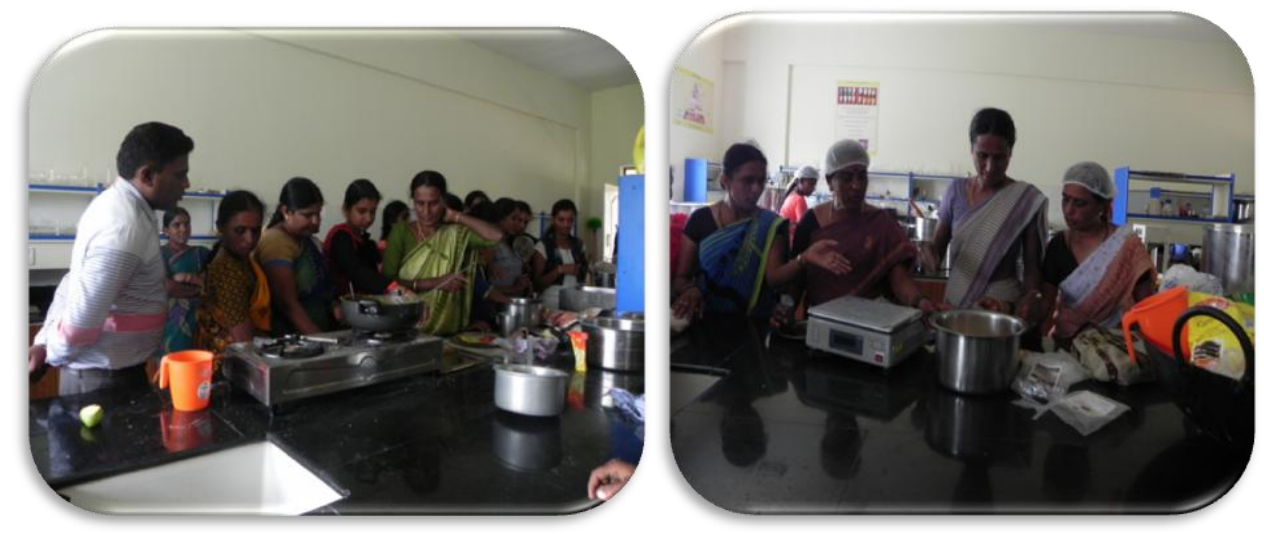

Vocational Training programme conducted at ICAR-KVK, Kolar
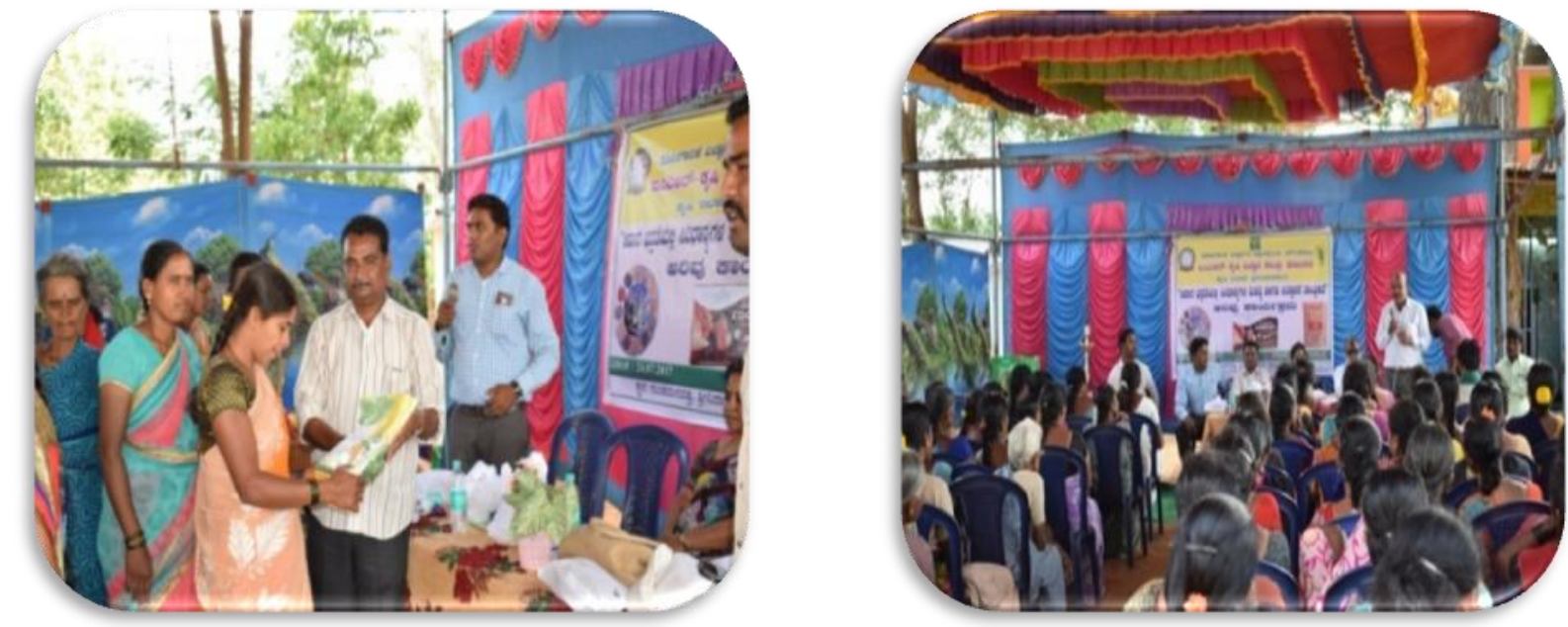

Awareness programme on "Production technology and their value addition of Minor Millets" at Gundamanatta on 24.7.2017


Minor Millers processing unit have established at Guddamanatta 

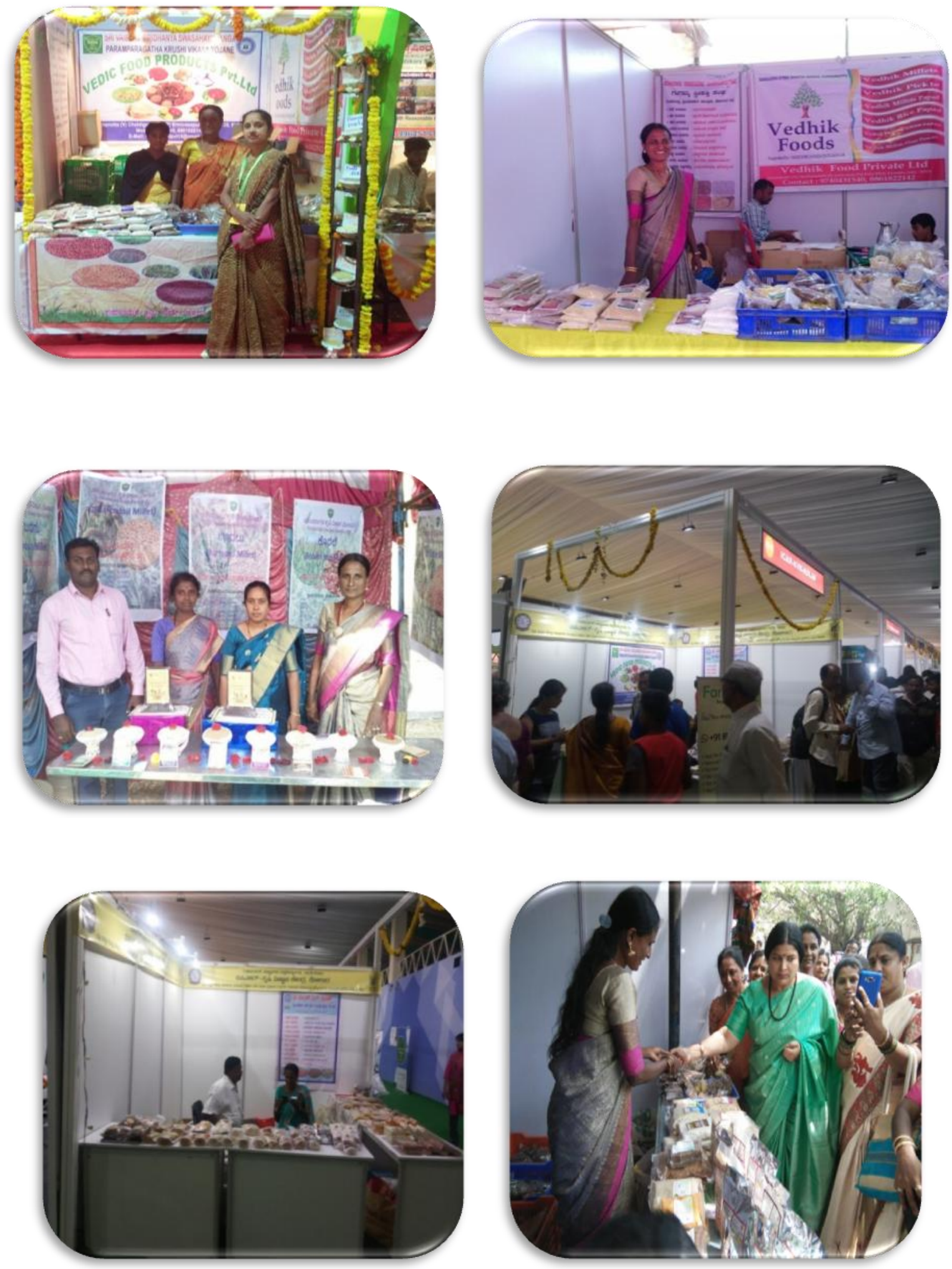

Display and sale of Value Added products at different places like Exhibitions and Melas 


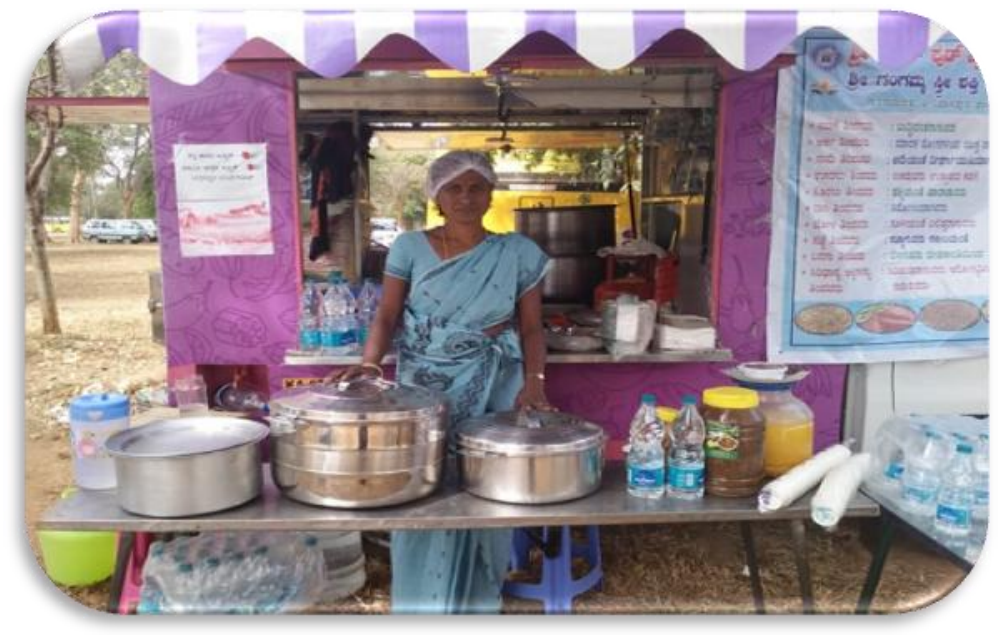

Savi Ruchi Canteen at DC Office, Kolar
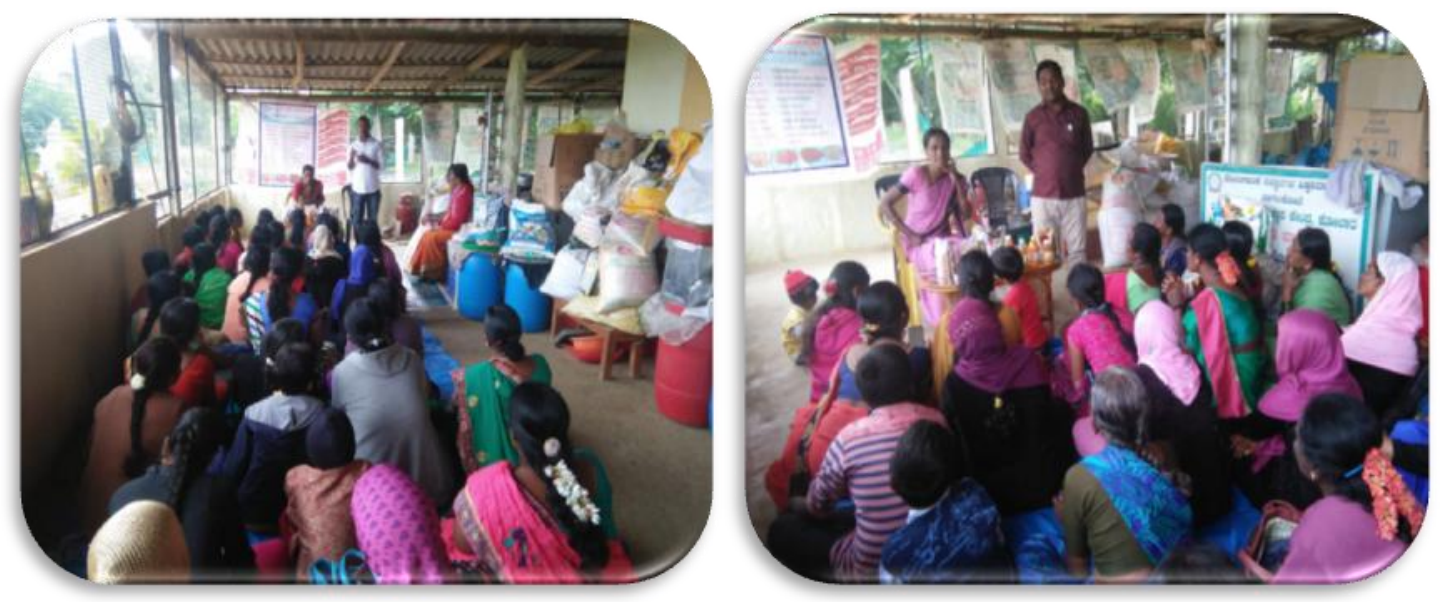

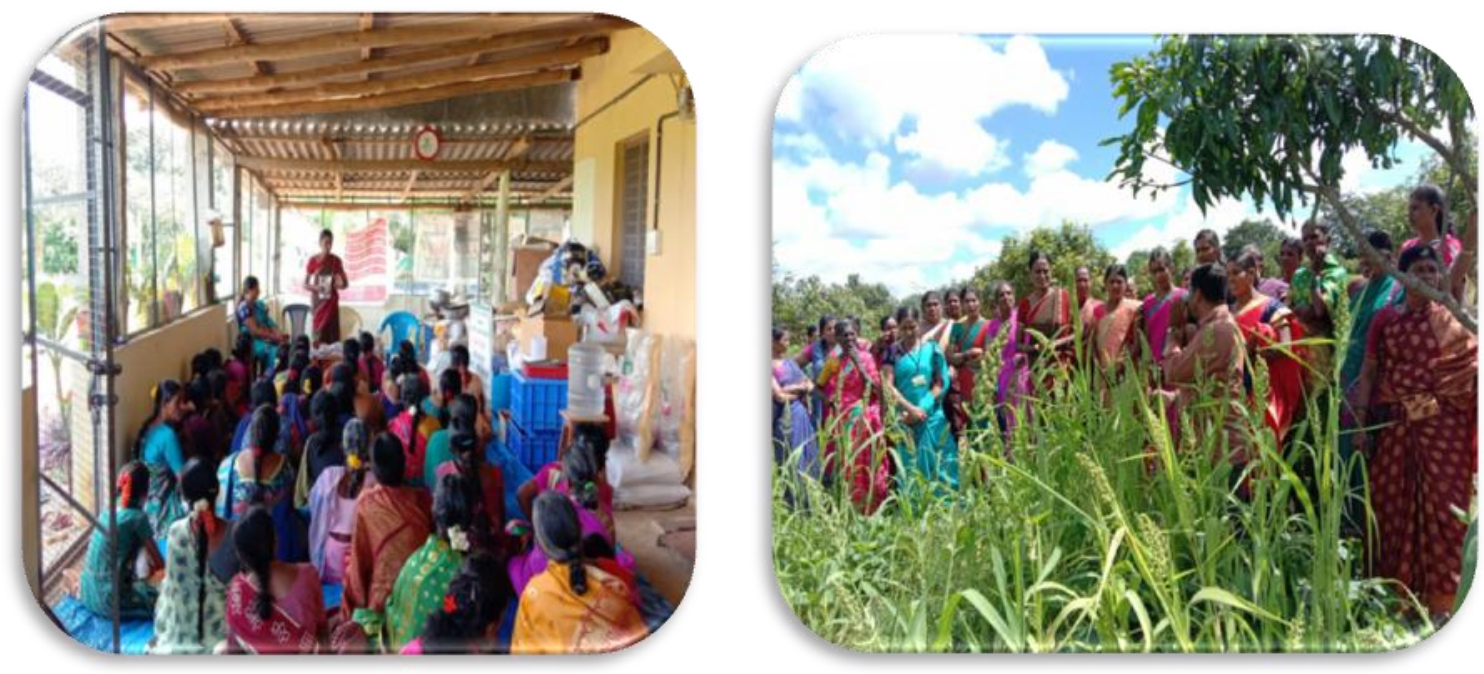

Training programmes has conducted at Gundamanntha, Srinivasapura TQ
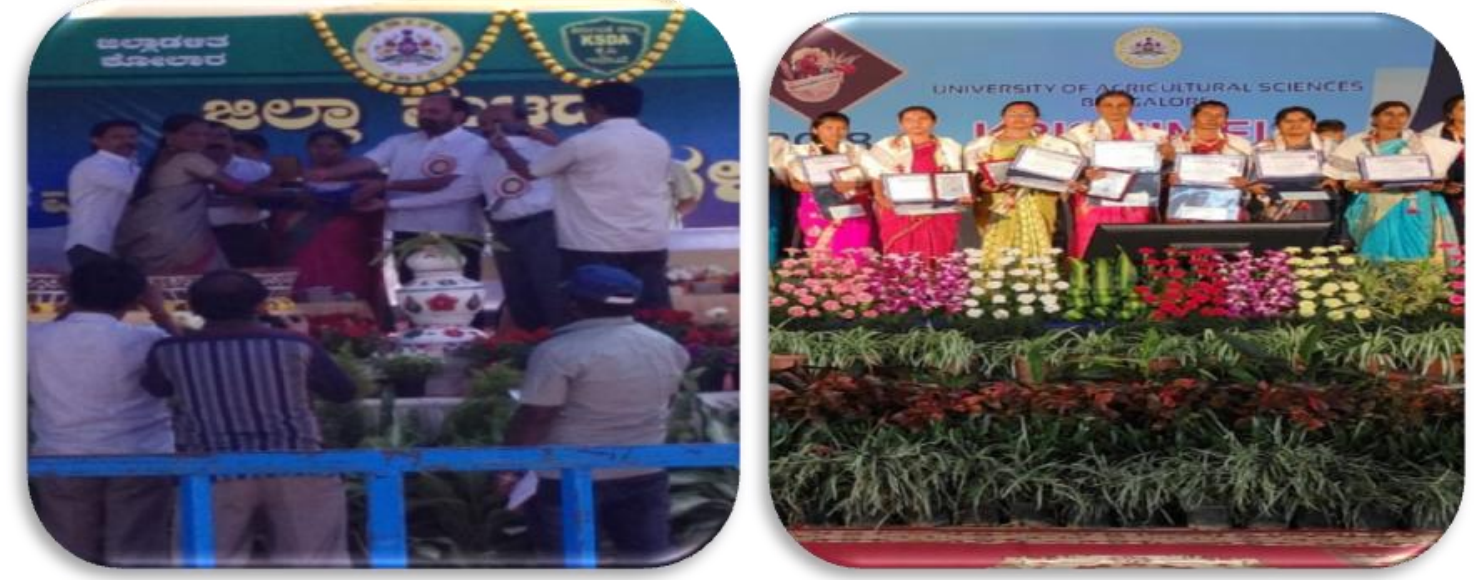

District level Award received at Minor millets and Best Farmers Award by UAS,GKVK, Bangalore flower show Organized by Department of Horticulture
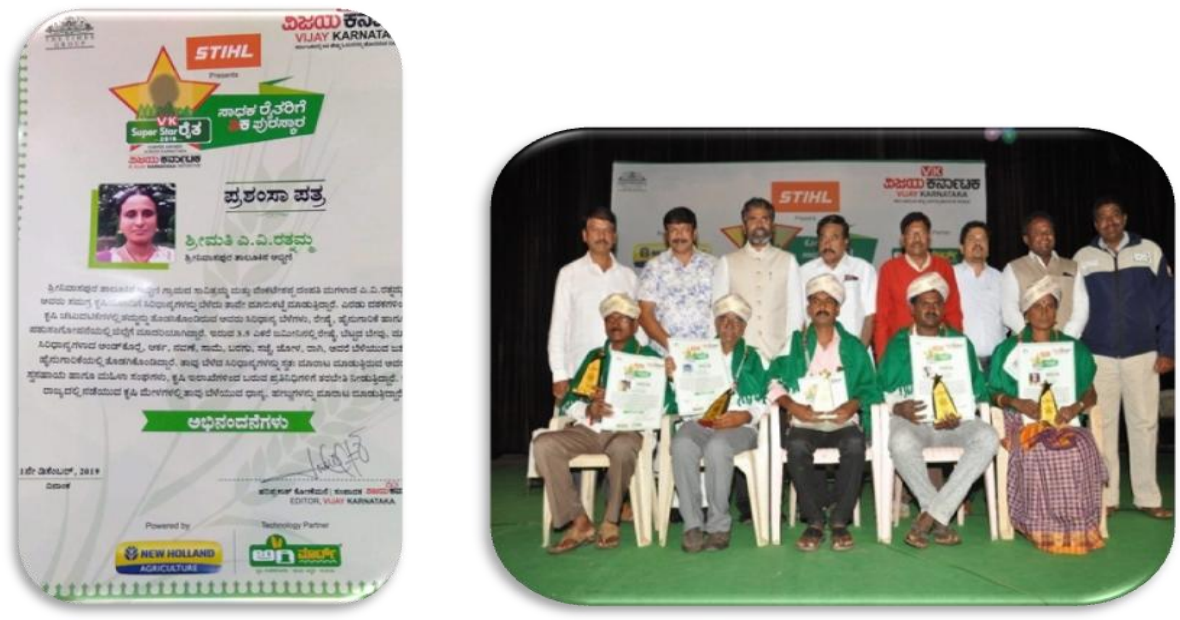

Super Star Raitha award from Vijay Karnataka 


\section{Economic gains}

The entrepreneur had expressed the details of income generated was Rs. 224100/-. This results in the net profit of Rs. 1,29,850/-and $\mathrm{B}: \mathrm{C}$ ratio was 1:1.72 in the year 2017-18. The entrepreneur had expressed the details of income generated was Rs. 1,11,5780/-. This results in the net profit of Rs. 4,80,000/- and $\mathrm{B}: \mathrm{C}$ ratio 1:2.32 in the year 2018-19.

Master trainee for conducting Minor Millets value addition results as we have identified her as master trainee to conduct hands on training programme on processing ,value addition and marketing of minor millets value added products. She has been conducting training programme to SHG and adolescent girls.

\section{Awards recognition}

She was awarded first prize in food show organized by Department of Women and child development, Kolar and minor millets and flower show arranged by Department of Horticulture, Kolar. She was awarded best farmers award taulk level by UAS Bangalore.

\section{Future Prospects}

Promotion of Nutri cereal for consumption among the people is need the hour

India have more than 20000 ha area of fallow land

Scope for research is more in production of fortified foods by using nutri cereal

This is one of the promising means for achieving the goal of doubling the farmers income.

Significant Achievements made under the
Vocational training:

Under the Vocational training total 20 SHG members from Gundamanttha Srnivasapura $\mathrm{Tq}$ have been trained for preparing different value added products from Minor Millets.

- One processing unit of Minor Millets have been established at Gundamanttha Srnivasapura Tq and she earned Rs. 480000 per year.

- Marketing of products being prepared by beneficiaries, under the project have been done through Krishi melas, Dasara Festival, Udyana Mela, Mago and Jackfruit Mela, Lalbagh Bengaluru, Flower Show organized by Dept.Horticulture, Kolar , and KVK programmes. Thus good market has been provided to the beneficiaries.

- This unit creates good employment generation in the villege for SHG members.

This project given an opportunity to rural as well as urban consumer to purchase good quality Minor Millets value added products at reasonable price.

\section{References}

Gopalan C, RBV Sastri and SC

Balasubramanian (1996) NutritiveValue of Indian Foods. NIN, ICMR offset press, ICMR, New Delhi.

D Vijayalakshmi, K Geetha, Jayarame Gowda, S Bala Ravi, S Padulosi and Bhag Mal4Empowerment of Women Farmers through Value Addition on Minor Millets Genetic

Resources: A Case Study in Karnataka Indian J. Plant Genet. Resour. 23(1): 132-135 (2010). 
How to cite this article:

Chikkanna G. S., K.Thulasiram B. G. Prakash, D. S. Ambika, K. R. Shashidar and Anilkumaur, K. S. 2020. Women Empowerment through Processing and Marketing of Minor Millets Value Added Products: A way for Doubling The Farmers Income. Int.J.Curr.Microbiol.App.Sci. 9(01): 1446-1456. doi: https://doi.org/10.20546/ijcmas.2020.901.160 